Tot leden van het Instituut worden voorgesteld en aangenomen de hh. N. J. Struick, Inspecteur van financiën in N.-I., thans met verlof te 's Gravenhage, en J. F. Niks, laatst hulppredider op Timor, mede hier te lande met verlof, te Utrecht.

Niets meer hierna aan de orde zijnde, wordt de vergadering door den Voorzitter gesloten.

\title{
2995TE BESTUURSVERGADERING
}

GEHOUDEN 19 JANUARI 1889.

Tegenwoordig de hh. Kern (Voorzitter), Kielstra (Ondervoorzitter), J. H. de Groot (Penningmeester), Humme, Niemann, Riedel, Martin, Snouck Hurgronje, Wilken en Wijnmalen (Secretaris). Afwezig, met kennisgeving, de hh. Bool en de Roo.

De notulen van het verhandelde in de vorige vergadering worden gelezen en goedgekeurd.

Naar aanleiding van hetgeen in de notulen voorkomt omtrent den herdruk der Bloemlezing uit Maleische geschriften vraagt de heer Niemaun het woord en zegt dat, afgescheiden nog van de vele bezwaren, die er bij hem ter bezorging van een herdruk van bedoeld werk rijzen, het hem bovendien bij nader onderzoek gebleken is, dat die herdruk niet zoo dringend noodig is, daar de weinige nog aanwezige exemplaren voldoende geacht worden om in de eerste behoefte te voorzien. Hij stelt daarom voor om terug te komen op het genomen besluit en vooralsnog althans niet over te gaan tot de bezorging eener nieuwe uitgave zijner Bloemlezing.

Dienovereenkomstig wordt besloten, terwijl, naar aanleiding der mededeelingen van den Secretaris onder overlegging der door hem met de heeren Nijhoff en Trap gevoerde correspondentie, goedgekeurd wordt, dat, indien men later er toe zou willen overgaan een herdruk der Bloemlezing te leveren, men dit niet zou doen plaats hebben dan ná over de voorwaarden in nader overleg te zijn ge- 
treden met onzen uitgever Nijhoff in verband met het schrijven des heeren Trap.

De Secretaris vestigt de aandacht der vergadering op de sedert de vorige bijeenkomst ingekomen boekwerken, terwijl hij tevens mededeeling doet van een door hem ontvangen schrijven van den heer Wm Campbell, waarbij voor het Instituut een exemplaar wordt aangeboden van een herdruk van Graevius' vertaling van het Evangelie van Mattheus in het Formosaansch.

Plaatsing der ontvangen boekwerken in de Bibliotheek, onder dankbetuiging aan de inzenders.

De Voorzitter deelt mede, dat zijn ingekomen:

10. missives van de heeren W. A. Arriëns, C. J. van Beresteyn, R. van Eck, G. J. Grashuis, A. S. H. van Kappen, N. van Taack Trakranen, F. L. Geerling en Jhr. mr. H. C. van der Wijek, allen houdende verzoek om met den aanvang van het dienstjaar 1889 hunne namen van de ledenlijst af te voeren.

Hiervan wordt aanteekening gehouden, voor zooveel betreft de zes eerstgenoemden, terwijl de Secretaris bericht dat aan de beide laatstgenoemde heeren is medegedeeld, dat aan hun verzoek zal worden voldaan aan het einde van het loopend jaar, daar hunne aanvrage om ontslag eerst ná de intrede van het dienstjaar werd ontvangen.

20. missives van de heeren N. J. Struick, te 's Gravenhage en J. F. Niks, te Utrecht, houdende bericht dat zij gaarne het lidmaatschap van het Instituut wenschen te aanvaarden.

Voor kennisgeving aangenomen.

Ingevolge eener door den Secretaris met den heer mr. A. C. P. Lammers van Toorenburg, advocaat te 's Graveuhage, gevoerde correspondentie, wordt genoemde heer door hem als lid van het Instituut voorgedragen, en door de vergadering daartoe benoemd.

Overeenkomstig den imhoud van de door den Secretaris ontvangen brieven wordt aangeteekend, dat de heer K. I. van Schouwenburg, laatst Directeur der Hoogere Burgerschool te Semarang, thans met verlof hier te lande, zich met der woon te Haarlem gevestigd heeft, terwijl, daar het lid C. Poensen weldra Kediri zal verlaten en naar Nederland terugkeeren, de voor hem bestemde uitgaven van het 
Instituut moeten worden geadresseerd en verzonden naar het Zendinghuis te Rotterdam.

Ter tafel wordt gebracht een schrijven van den heer Th. Delprat, Ingenieur der 1e klasse bij den dienst der Staatsspoorwegen ter Sumatra's Westkust, te Fort de Kock, dd. 9 December 1888, bevattende uitvoerige mededeelingen omtrent eenige zeer belangrijke monumenten, die van onze vroegere Oost-Indische Compagnie op het schiereiland Malakka zijn overgebleven en uitstekend bewaard zijn: een en ander naar aanleiding van eene circulaire van den Gouverneur-Generaal van N.-I., uitgevaardigd ten gevolge van een rekwest van het Instituutsbestuur aan den Minister van Koloniën d.d. 4 Juni 1888, betreffende het verzamelen van bouwstoffen voor een eventueel samen te stellen Lapidarium van onze koloniën.

Op voorstel des Voorzitters wordt besloten het schrijven des heeren Delprat te voegen bij de reeds vroeger ontvangen stukken betreffende het Lapidarium en in handen te stellen van den heer Bool, terwijl aan den Schrijver voor zijne belangstelling zal worden dankgezegd.

De Secretaris herimnert, dat geruimen tijd geleden door tusschenkomst van den Penningmeester een aantal boekwerken, door het Instituut in de Javaansche en Maleische talen uitgegeven, naar Indië gezonden is, met verzoek om bericht of en op welke wijs de verkoop daarvan zou kunnen worden bevorderd. Hieromtrent worden bij een schrijven dd. 12 December 1888 van de firma G. C. T. van Dorp, te Semarang, aan den Penningmeester inlichtingen verstrekt, waaruit blijkt, dat het debiet der evenvermelde fondsartikelen van het Instituut in de laatste drie jaren telkens minder is geworden en in het verloopen jaar treurig geweest is, hetgeen aan den maatschappelijken toestand van den inlander moet worden toegeschreven, die thans voor dergelijke zaken geen geld heeft, terwijl alléén dan iets verkocht wordt, indien men een zeer lang crediet kon toestaan. In den Catalogus der fondsartikelen van het Instituut komt echter slechts een boek voor, de Kitab Toepah, waarnaar nog meermalen wordt gevraagd, doch daar dit werk, blijkens ontvangen inlichtingen uitverkocht is, zou men gaarne de vergunning willen erlangen een nieuwen druk daarvan uit te geven, zoo althans het Instituut geen plan mocht hebben het zelf te doen herdrukken, terwijl men voor het recht. daartoe gaarne eene geldelijke bijdrage van $f 100$ à $f 150$ zou willen beschikbaar stellen, 
De Voorzitter zegt den Penningmeester dank voor zijne bemoeiingen en voor de mededeelingen, die daardoor zijn uitgelokt en stelt voorts aan de orde de vraag, of de aanbevolen herdruk van de Kitab Toepah vanwege het Instituut zal geschieden. Na gedachtenwisseling wordt daarop eenparig in ontkennenden zin geantwoord, doch, overeenkomstig het voorstel van den Voorzitter, besloten, aan de firma van Dorp te melden, dat het Instituut, zelf ongenegen een herdruk van de Kitab Toepah te leveren, na rijp beraad gaarne haar aanbod vervaardt om haar het recht tot den herdruk te verleenen tegen een geldelijke bijdrage van $f 150$, zoo althans bij onderzoek blijken mocht, dat het Instituut zelf alsnog het copierecht van het werk bezit.

De Penningmeester brengt ter tafel de rekening en verantwoording van zijn beheer over het afgeloopen dienstjaar. In handen gesteld van de heeren Humme en Kielstra, ten einde daarover in de volgende vergadering rapport uit brengen, terwijl daarna eene Commissie uit de gewone leden, waartoe worden aangewezen de heeren P. M. Netscher en G. C. Klerk de Reus, met het onderzoek der rekening zal worden belast, met opdracht, der Algemeene Vergadering daaromtrent te dienen van bericht en raad.

Overeenkomstig het voorstel van den Secretaris wordt goedgekeurd de volgende Bestuursvergadering op den 16n Februari te houden, en den 23en daaraanvolgende de Algemeene Vergadering bijeen te roepen, waarop aan de orde zullen worden gesteld: $1^{0}$. het verslag over den staat eu de lotgevallen van het Instituut over het jaar 1888; 20. de rekening en verantwoording over hetzelfde tijdperk; 30. de vervulling van vier vacatures in het Bestuur tengevolge der aftreding der heeren Humme, Riedel en de Roo en het ontslag van Dr. Snouck Hurgronje, wegens zijn vertrek naar Indië; en eindelijk $4^{0}$. de mededeeling omtrent de keuze van leden van het Instituut.

Naar aanleiding van de bespreking van den inhoud der eerstvolgende aflevering van de Bijdragen wordt goedgekeurd dat daarin een opstel van Dr. Grabowsky en de vervolg-studiën van de heeren Kielstra en Niemann, vermoedelijk ook die van den heer Wilken, zullen kunnen worden opgenomen, benevens eene bijdrage van Dr. ten Kate, omtrent de plaatsing waarvan en het drukken van de daarbij behoorende platen de Sejeretaris gemachtigd wordt vooraf het advies van het medelid Martin in te winnen, 
Onder dagteekening van 6 Januari jl. is van het Bestuur van het Indisch Genootschap een schrijven ontvangen, waarbij wordt voorgesteld het uur van opening der bibliotheken van het Instituut en Genootschap te vervroegen. Mochten daartegen onoverkomelijke bezwaren bestaan, dan zou het, ten einde den wensch van sommige leden te bevredigen, aanbeveling verdienen om op een tweetal dagen in de week, bijv. des Maandags en Donderdags, de bibliotheken toegankelijk te stellen van 10 tot 2 uren en de andere dagen op de gewone uren van 12 tot 4 uren.

Bij de bespreking van dit voorstel blijkt, dat, waar, naar de meening van het Bestuur van het Indisch Genootschap, sommige leden de keuze van de openingsuren niet gelukkig vinden, verreweg de meeste der buiten 's Gravenhage wonende leden juist aan de thans vastgestelde tijden boven de ochtenduren de voorkeur geven en ongaarne eene verandering zouden zien gemaakt, terwijl bovendien de weinige leden, die voor bepaalde studiën reeds in de ochtenduren tot de verzamelingen wenschten toegelaten te worden, na voorafgaande aanvrage bij den Secretaris-Bibliothecaris, daartoe telkens met de meeste bereidwilligheid verlof hebben verkregen. Vooral ook op grond van de aan het voorstel verbonden financieële bezwaren wordt de aanneming daarvan door den Secretaris ontraden, die, zoo men toch verandering wil, eerder de openstelling der verzamelingen op elken werkdag van $10-4$ uur zou anbevelen, doch alleen zoo het Genootschap bereid is een tegemoetkoming in de meerdere kosten van toezicht, verwarming, enz. te verleenen.

Overeenkomstig het voorstel van den Voorzitter wordt besloten aan het Bestuur der Zusterinstelling mede te deelen, dat men aan het voorstel gevolg wil geven, zelfs bereid is een stap verder te gaan en de verzamelingen elken werkdag toegankelijk te stellen van 10-4 uren, mits het Genootschap zijnerzijds ook genegen worde bevonden de meerdere kosten, die de invoering van den voorgestelden maatregel noodwendig na zich sleept, te vergoeden.

De Penningmeester deelt mede, dat de fondsen van het Instituut hem reeds nu in staat hebben gesteld een gedeelte der drukkosten van Dr. Snouck Hurgronje's "Mekka", tot een bedrag van $f 2000$ te voldoen. Voor kennisgeving aangenomen.

Door den - heer Snouck Hurgronje, die meêdeelt dat de uitgave van de Atjehsche Spraakkunst en het Atjehsche Woordenboek 